\title{
Decreased expression of thyrotropin receptor gene suggests a high-risk subgroup for oncocytic adenoma
}

\author{
Delphine Mirebeau-Prunier ${ }^{1}$, Serge Guyétant ${ }^{2}$, Patrice Rodien ${ }^{1,4}$, Brigitte Franc ${ }^{3}$, Olivier Baris ${ }^{1}$, \\ Vincent Rohmer $^{1,4}$, Pascal Reynier ${ }^{1}$, Yves Tourmen ${ }^{1}$, Yves Malthièry ${ }^{1}$ and Frédérique Savagner ${ }^{1}$ \\ ${ }^{1}$ INSERM E 00-18 Laboratoire de Biochimie et Biologie moléculaire, CHU, Angers F-49033, France, ${ }^{3}$ Laboratoire d'Anatomie Pathologique, \\ Hôpital Ambroise Paré, AP-HP, Boulogne F-92104, France and ${ }^{2}$ Laboratoire d'Anatomie Pathologique and ${ }^{4}$ Service d'Endocrinologie (P R), \\ Nutrition et Médecine interne, CHU, Angers F-49033, France
}

(Correspondence should be addressed to D Mirebeau-Prunier, INSERM E O0-18 Laboratoire de Biochimie et Biologie moléculaire, CHU, 4 rue Larrey F-49033 Angers Cedex 01, France; Email: DeMirebeau-Prunier@chu-angers.fr)

\begin{abstract}
Objective: The malignancy of thyroid oncocytic tumours, or oncocytomas, is higher than that of follicular tumours. The aim of this study was to investigate the role of thyroid-specific genes in oncocytic tumours and papillary carcinomas.

Design and methods: We compared 29 oncocytic tumours with 12 papillary carcinomas. Real-time quantitative PCR was used to measure the expression of thyroid-specific differentiation markers (thyrotrophin-stimulation hormone receptor (TSHR), thyroglobulin (TG) and $\mathrm{Na}^{+} / \mathrm{I}^{-}$symporter (NIS)), transcription factors (thyroid transcription factor-1 (TTF-1) and paired box gene-8 (PAX8)) and nuclear receptors (peroxisome proliferator-activated receptor (PPAR $\gamma 1$ ) and thyroid hormone receptor (TR $\beta 1)$ ) involved in thyroid carcinogenesis.

Results: TSHR, TTF-1 and TR $\beta 1$ levels were significantly lower in oncocytic tumours than in papillary carcinomas, as a result of specific biological changes in oncocytic tumours. However, PAX8 and PPAR $\gamma 1$ did not seem to be involved in the process. Applying the criterion of the underexpression of the thyroid-specific differentiation markers, TSHR, TG and NIS, we classified the oncocytic tumours and papillary carcinomas into three groups. In the first, all three markers were underexpressed; in the second, TSHR was normal while TG and NIS were underexpressed; and in the third, only NIS was underexpressed. The expression patterns revealed that 13 of the 24 oncocytic adenomas underexpressing TSHR in our study, as did four of the five oncocytic carcinomas.

Conclusion: Cases of oncocytic adenoma associated with four levels of TSHR could be putative oncocytic carcinomas and should therefore receive adequate follow-up.
\end{abstract}

European Journal of Endocrinology 150 269-276

\section{Introduction}

Oncocytes are epithelial cells characterised by an abundant cytoplasm that takes on a finely granular eosinophilic staining, indicating the presence of large numbers of mitochondria (1). These cells, frequently found in organs with high metabolic activity, are associated with inflammation, degenerative processes and cellular ageing. Oncocytes undergo neoplastic transformation but oncocytic tumours or oncocytomas are rare, except in the thyroid and the kidney (2). Oncocytic adenomas and carcinomas or Hürthle cell thyroid tumours represent a distinct subgroup of follicular tumours. In these tumours, capsular and vascular invasions occur more frequently than in non-oncocytic follicular tumours. Moreover, the mortality rate is higher in oncocytic carcinomas than in papillary or follicular carcinomas (3). The relatively high rate of malignancy and aggressiveness of thyroid oncocytic tumours contrasts with the benign nature of most oncocytic tumours in other organs $(4,5)$.

In the normal thyroid, the growth and differentiation of follicular cells are mainly regulated by the thyrotrophin-stimulating hormone (TSH) through its receptor (TSHR), a member of the family of G-protein-coupled receptors. Stimulation of TSHR activates two major signal-transduction pathways: the adenylcyclase pathway through the guanine nucleotide-binding protein alpha subunit (GNAS) and the phospholipase $C$ pathway through the Gq protein alpha subunit (6). Somatic mutations of TSHR and GNAS genes have been previously reported in toxic adenomas as well as in thyroid follicular carcinomas (7-9). Differentiated thyroid cells express the TSHR, thyroglobulin (TG), thyroperoxidase (TPO) and the $\mathrm{Na}^{+} / \mathrm{I}^{-}$symporter (NIS) genes. The expression of these genes is controlled by specific transcription factors: thyroid transcription factors 1 and 2 (TTF-1 and TTF-2), and paired box gene-8 
(PAX8). Different combinations of these transcription factors bind to promoters of TSHR, TG and NIS, playing an important role in the determination and the maintenance of the differentiated thyroid phenotype. Although the TSHR and NIS genes, as well as the TTF1 and PAX8 transcription factors, are expressed in various other tissues, their co-expression is exclusive to the thyroid cell. During human thyroid tumourigenesis, these genes and transcription factors undergo different stages of alteration resulting in the primary loss of NIS expression followed successively by that of TSHR, TG and TPO (10). In fact, the degree of thyroid tumour dedifferentiation is correlated with the loss of expression of the thyroid-specific transcription factors $(11,12)$.

The expression of TSHR is modulated by triiodothyronine (T3) through the T3 nuclear receptor TR $\beta 1$ (13). In most papillary carcinomas, and in some follicular carcinomas, the decreased expression of the TR $\beta$ gene is due to the occurrence of inactivating mutations $(14,15)$. Peroxisome proliferator-activated receptor- $\gamma$ (PPAR $\gamma)$, another nuclear receptor, participates in follicular tumourigenesis through its rearrangement with PAX8 $(16,17)$. The PAX8-PPAR $\gamma 1$ fusion protein, which suppresses the wild-type activity of PPAR $\gamma 1$, is present in follicular adenoma as well as in carcinoma (18).

In our study of 29 follicular thyroid oncocytic tumours, we have analysed the expression of seven genes: three thyroid-specific genes, TSHR, TG, and NIS; two transcription factors, TTF-1 and PAX8; and two nuclear receptors, PPAR $\gamma 1$ and TR $\beta 1$. We have chosen papillary carcinoma rather than follicular cancer as control because of their known aggressiveness, their well-established molecular characterisation and their richness in mitochondria. Furthermore, papillary carcinomas are the most frequent malignant tumours arising from follicular cells. Our aim was to investigate the role of thyroid-specific genes and transcription factors in thyroid oncocytic carcinogenesis.

\section{Materials and methods}

\section{Thyroid tissue samples}

The study included 29 follicular oncocytic thyroid tumours and 12 papillary thyroid carcinomas. All the samples used were rendered anonymous (i.e. all patient identifiers were deleted before the study). The samples studied were obtained from consecutive cases, unselected apart from exclusions for insufficient material. Twenty-four of the tumours were diagnosed as follicular oncocytic adenomas and five as follicular oncocytic carcinomas, according to the World Health Organisation classification (19). The assessment of malignancy was based on vascular or capsular invasion. The 29 follicular oncocytic tumours (average size, $2.74 \pm 1.51 \mathrm{~cm}$ ) were found in three men and
26 women (mean age, 51.4 years). The 12 papillary carcinomas (average size, $2.51 \pm 0.96 \mathrm{~cm}$ ) were found in one man and 11 women (mean age, 40.4 years).

Thirty-six paired normal thyroid samples (29 for follicular oncocytic tumours and seven for papillary carcinomas) were taken distant from the tumour and checked on histology to serve as controls. All the samples were frozen immediately after resection and stored in liquid nitrogen until used.

\section{RNA isolation and CDNA synthesis}

RNA was isolated using the guanidium isothiocyanate procedure (Trizol Reagent, Invitrogen). Quantification, degradation and DNA contamination of RNA were assessed using an RNA 6000 nano assay (Agilent Technologies, Palo Alto, CA, USA). The reverse transcription (RT) was performed on $1 \mu \mathrm{g}$ RNA with Advantage RT-for-PCR kit (Clontech) following the manufacturer's recommendations.

\section{Quantitative PCR analysis}

Real-time quantification was performed using SYBR Green I dye (Faststart DNA Master SYBR Green I, Roche) as a fluorescent signal. The dye binds specifically to the minor groove of double-stranded DNA, allowing the detection of PCR product formation. Seven genes (TSHR, NIS, TG, PAX8, TTF-1, PPAR $\gamma 1$ and TR $\beta 1$ ) and one reference gene ( $\beta$-ACTIN) were explored. The amount of cDNA from the different genes was normalised by quantification of $\beta$-ACTIN as described elsewhere (20). Templates $(2 \mu \mathrm{l})$ were added to the PCR reaction mixture containing $2 \mu \mathrm{l}$ of master mix including Taq DNA polymerase, dNTPs and SYBR Green I, $1 \mu \mathrm{M}$ each of forward and reverse primers, $\left(0.5 \mu \mathrm{M}\right.$ for TSHR) and $4 \mathrm{mM} \mathrm{MgCl}_{2}(3 \mathrm{mM}$ for TSHR), in a final volume of $20 \mu \mathrm{l}$. The primers used for quantitative PCR are specified in Table 1.

Each series of PCR reactions included a standard curve, established using serial dilutions of a plasmid (PCR2.1-TOPO Invitrogen) containing the different PCR products amplified from a normal thyroid tissue on histology. All analyses were performed in duplicate on the Lightcycler apparatus (Roche) and included one negative and one positive control. The PCR amplification protocol consisted of initial denaturation at $95^{\circ} \mathrm{C}$ for $10 \mathrm{~min}$ followed by 40 cycles of denaturation at $95^{\circ} \mathrm{C}$ for $1 \mathrm{~s}$, annealing for $10 \mathrm{~s}$ (temperature indicated in Table 1) with an extension at $72{ }^{\circ} \mathrm{C}$ for $10 \mathrm{~s}$. The concentration of each gene was calculated on the basis of the respective calibration curve. Relative copy numbers of TSHR, NIS, TG, PAX8, TTF-1, PPAR 1 and TR $\beta 1$ were then obtained by calculating the ratio of each gene on $\beta$-ACTIN. The normalised $\beta$-ACTIN ratio for a gene in the tumour sample $\left(R_{t}\right)$ was compared to that of the same gene in the normal sample $\left(R_{\mathrm{n}}\right)$. Four papillary carcinomas without normal 
Table 1 Primers and conditions used for real-time quantitative RT-PCR.

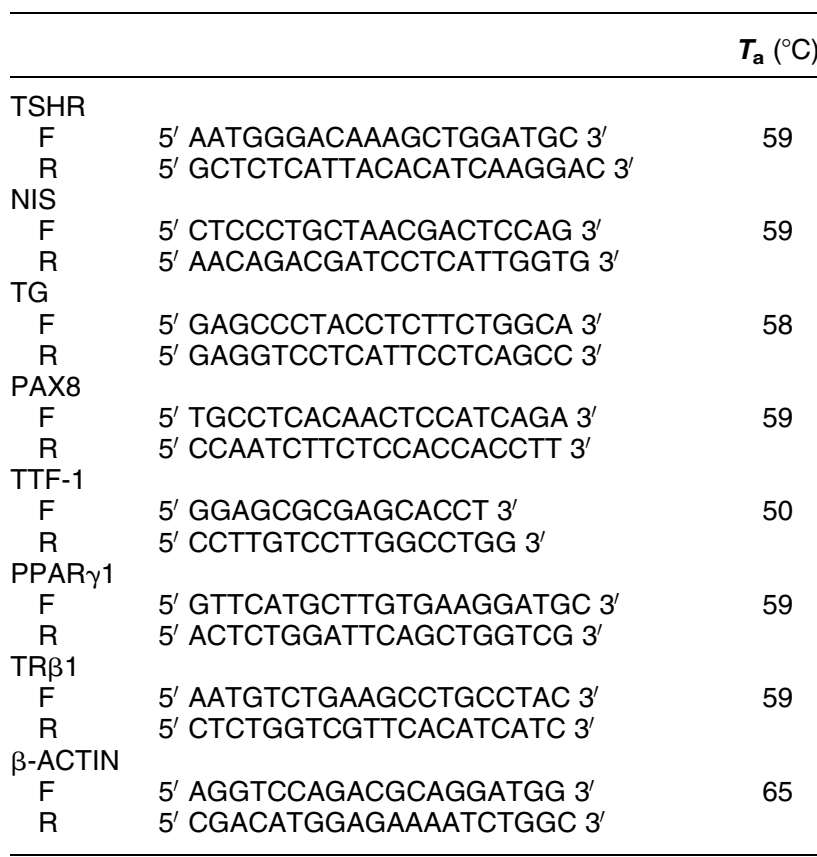

$T_{\text {a }}$, annealing temperature for PCR; $F$, forward; $\mathrm{R}$, reverse.

thyroid tissue controls were arbitrarily paired with other normal thyroid tissues in this study, according to the most similar amount of $\beta$-ACTIN cDNA. When the $R_{\mathrm{t}} / R_{\mathrm{n}}$ ratio was between 0.75 and 1.25 (95\% confidence interval for normal thyroid tissue) the gene expression in the tumour was considered to be equivalent to that in normal tissue. Inter-assay $(n=4)$ and intra-assay $(n=8)$ coefficients of variation were, on average, 17 and $6.3 \%$ respectively.

The specificity of amplification products was checked by plotting the melting curves obtained by means of the Lightcycler software.

\section{cDNA sequencing}

In 19 thyroid follicular oncocytic adenomas, 5 follicular oncocytic carcinomas and 14 samples of healthy thyroid tissues, the following genes were sequenced: the entire cDNA products of TSHR and TTF-1; exons 7 to 10 of TR $\beta 1$; exons 8 and 9 of GNAS.

cDNA $(3 \mu \mathrm{l})$ was amplified in a $40 \mu \mathrm{l}$ reaction mixture containing 2.5 U Taq polymerase (Hot Gold Star, Eurogentec SA, Liège, Belgium), $1 \mu \mathrm{M}$ of each primer, 0.2 mM dNTP (dNTP Master Mix, Eurogentec), $1.6 \mathrm{mM} \mathrm{MgCl}_{2}$ and $1 \times$ buffer. As TTF- 1 cDNA has a high GC content, betaine or dimethyl sulphoxide (DMSO) was added to the reaction buffer. The primers used for amplification are specified in Table 2. The PCR protocol consisted of initial denaturation at $95^{\circ} \mathrm{C}$ for $10 \mathrm{~min}$, followed by 35 cycles of denaturation at
Table 2 Primers and conditions used for the cDNA amplification and sequencing.

\begin{tabular}{|c|c|c|}
\hline & & $T_{\mathrm{a}}\left({ }^{\circ} \mathrm{C}\right)$ \\
\hline \multicolumn{3}{|l|}{ GNAS } \\
\hline $\mathrm{F}$ & 5' CATGGGCTGCCTCGGAAC $3^{\prime *}$ & 57 \\
\hline $\mathrm{R}$ & $5^{\prime}$ CTTAGAGCAGCTCGTACTGAC 3' & \\
\hline \multicolumn{3}{|c|}{ - } \\
\hline $\mathrm{F} 1$ & $5^{\prime}$ GGAGGATGGAGAAATAGCCC 3' & 55 \\
\hline R1 & $5^{\prime}$ GTCCAGTGTTGAAAATGCCA $3^{\prime *}$ & \\
\hline $\mathrm{F} 2$ & $5^{\prime}$ CTCCСССТССTAAAGTTC $3^{\prime}$ & 53 \\
\hline $\mathrm{R} 2$ & $5^{\prime}$ TTCTTGCTATCAGTTCCTTC3 $3^{\prime *}$ & \\
\hline F3 & 5' CGTGTCTCAAACCAGTGTCA 3* & 53 \\
\hline R3 & $5^{\prime}$ TCAGGAACTTGTAGCCCATT $3^{\prime}$ & \\
\hline $\mathrm{F} 4$ & $5^{\prime}$ TACCCCCAAGTCCGATGAGT $3^{\prime *}$ & 56 \\
\hline R4 & $5^{\prime}$ AGTGAAGAAACCAGCCGTGT 3' & \\
\hline F5 & $5^{\prime}$ CACTCTGAGTACTACAACCA $3^{\prime *}$ & 59 \\
\hline R5 & $5^{\prime}$ TATGCCAGAGCAAGAGGGGT $3^{\prime}$ & \\
\hline F6 & $5^{\prime}$ GCTATGCCAAAGTCAGTATC $3^{\prime *}$ & 53 \\
\hline R6 & $5^{\prime}$ GGATTGGCACAGGAGTTA $3^{\prime}$ & \\
\hline $\mathrm{F} 7$ & $5^{\prime}$ CCTCTCATCACTGTTAGCAA $3^{\prime *}$ & 53 \\
\hline R7 & $5^{\prime}$ TAAGTTCCCCTACCATTGTG $3^{\prime}$ & \\
\hline \multicolumn{3}{|c|}{ 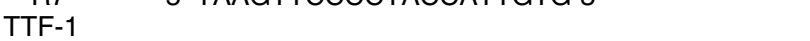 } \\
\hline $\mathrm{F} 1$ & 5' GCTTCGCCTTCCCCCTCTCC $3^{\prime}$ & 61 \\
\hline $\mathrm{R} 1$ & $5^{\prime}$ ATGTTGCCCAGGTTGCCGTT $3^{\prime *}$ & \\
\hline $\mathrm{F} 2$ & $5^{\prime}$ CAACGGCAACCTGGGCAA $3^{\prime *}$ & 57 \\
\hline $\mathrm{R} 2$ & $5^{\prime}$ GCGGCGACTGCTGCTGAG 3' & \\
\hline F3 & 5' CCCGCAGCAGCAACAGGC3 ${ }^{\prime *}$ & 57 \\
\hline R3 & $5^{\prime}$ CCGAGGAGTTCAGGTGGG 3' & \\
\hline $\mathrm{F} 4$ & $5^{\prime}$ TCCTGGTGAAAGACGGCA $3^{\prime *}$ & 54 \\
\hline $\mathrm{R} 4$ & $5^{\prime}$ AGCGGTGGATGGTGGTCT $3^{\prime}$ & \\
\hline \multicolumn{3}{|c|}{ 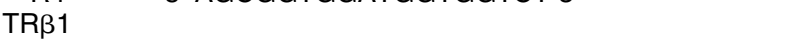 } \\
\hline $\mathrm{F} 1$ & $5^{\prime}$ TCTGAAGACATCAGCAGGAC $3^{\prime *}$ & 59 \\
\hline R1 & $5^{\prime}$ ACAGATTTGGTGCTGGATGA $3^{\prime}$ & \\
\hline $\mathrm{F} 2$ & $5^{\prime}$ AATTACCGAAAACACCACGT $3^{\prime *}$ & 57 \\
\hline $\mathrm{R} 2$ & $5^{\prime}$ TCCAGTCAGTCTAATCCTCG 3' & \\
\hline
\end{tabular}

$T_{\mathrm{a}}$, annealing temperature for PCR; $\mathrm{F}$, forward; $\mathrm{R}$, reverse. * Primers used for sequencing.

$95^{\circ} \mathrm{C}$ for $30 \mathrm{~s}$, annealing for $30 \mathrm{~s}$ (at temperatures indicated in Table 2) with an extension at $72^{\circ} \mathrm{C}$ for $1 \mathrm{~min}$.

Amplified fragments were purified and directly sequenced on a CEQ 8000 apparatus, using a CEQ DTCS Quick-start kit (Beckman Coulter, Fullerton, CA, USA) following the manufacturer's instructions. The primers used for sequencing are specified in Table 2.

\section{Statistical analysis}

Intergroup differences in the mRNA values were analysed using the Mann-Whitney $U$ test. Comparison between the level of thyroid-specific gene expression and the level of specific transcription factor expression were made using the Fisher exact test. The correlation between the expression of the different genes studied was investigated using STATVIEW software, version 5.0 (Abacus Concept, Berkeley, CA, USA). The differences were considered statistically significant at $P \leq 0.05$. 


\section{Results}

\section{The expression of TSHR, TG and NIS genes}

The expression of TSHR was significantly lower in oncocytic tumours $(P=0.002)$, but not in papillary carcinomas $(P=0.67)$, compared with normal paired
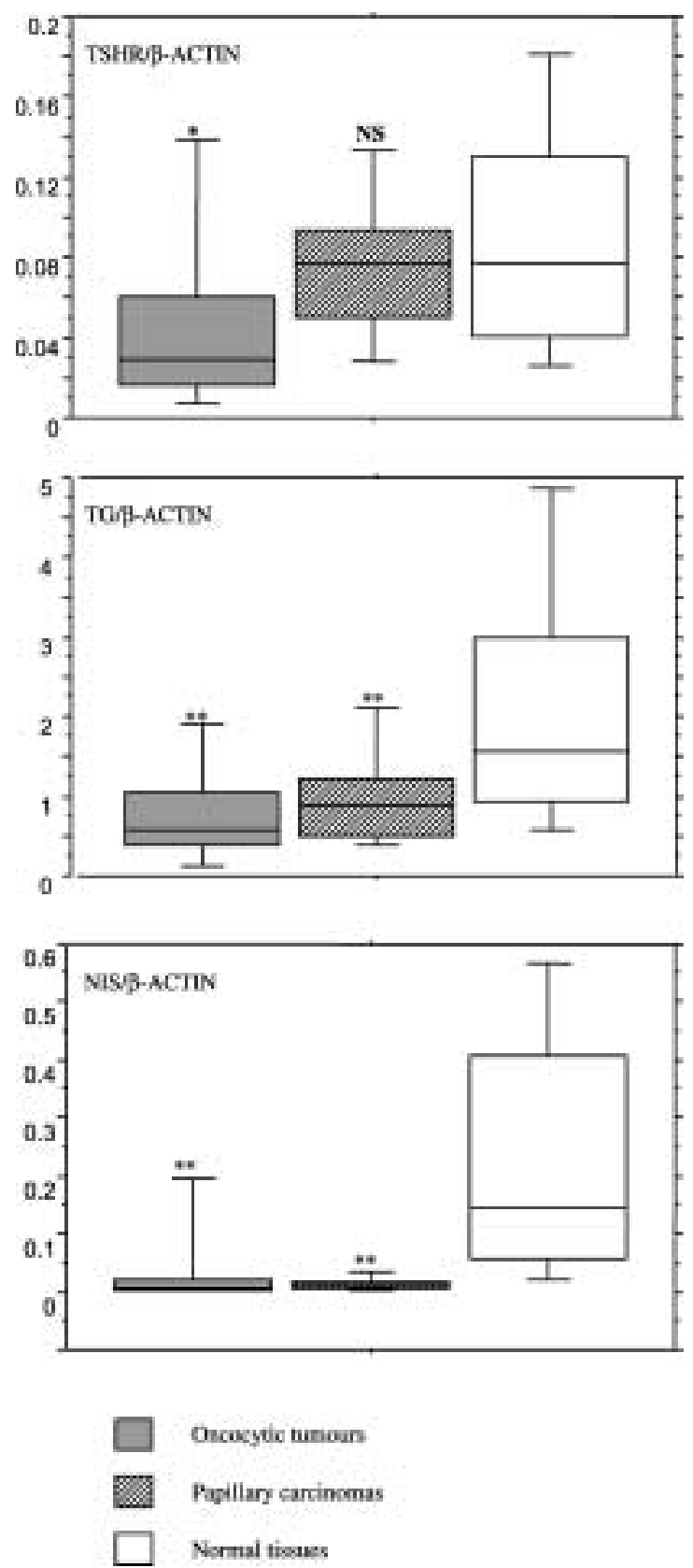

Figure 1 Box plots for TSHR, TG and NIS expression levels in 29 oncocytic tumours, 12 papillary carcinomas and 36 normal tissues by real-time quantitative PCR and after $\beta$-ACTIN normalisation. Boxes enclose interquartiles, error bars indicate 10th and 90th percentiles and centrelines indicate medians. ${ }^{* \star} P \leq 0.001$; ${ }^{\star} P \leq 0.05$; non-significant (NS), $P>0.05$. thyroid tissues. In contrast, the expression of the TG and NIS genes was significantly lower both in oncocytic tumours and in papillary carcinomas compared with normal paired thyroid tissues $(P \leq 0.001$, Fig. 1$)$.

We classified the tumours into three groups according to the expression of TSHR, TG and NIS genes (Fig. 2). The first group, the 'poorly differentiated' group (OT1), contained 13 oncocytic adenomas and four oncocytic carcinomas; the expression of TSHR, TG and NIS was lower than in paired control tissues. The second group, the 'moderately differentiated' group (OT2), contained four oncocytic adenomas and one oncocytic carcinoma; TSHR was normally expressed, while both TG and NIS were underexpressed. The third group, the[NBsp] 'well-differentiated' group (OT3), contained five oncocytic adenomas; only NIS was underexpressed. Two oncocytomas (Fig. 2: OTA 23, OTA 24) did not fit into any of these groups. In OTA 23, TSHR was moderately overexpressed, while TG and NIS were normally expressed. In OTA 24, TSHR was underexpressed, while TG and NIS were highly overexpressed.

The papillary carcinomas could be classified in a similar manner. Of the seven papillary carcinomas with paired control tissues, the three tumours that underexpressed TSHR, TG and NIS were classified as the "poorly differentiated' group (PC1), while the four tumours that underexpressed only NIS were classified as the "well-differentiated' group (PC3). Five papillary carcinomas without normal thyroid tissue controls were arbitrarily paired with normal thyroid tissues according to the $\beta$ ACTIN levels (indicated in italics in Fig. 2). Thus, two of these tumours, underexpressing TSHR, TG and NIS, were classified in the 'poorly differentiated' group (PC1), while three tumours, with normally expressed TSHR and underexpressed TG and NIS, were classified in the 'moderately differentiated' group (PC2).

\section{Expression of TTF-1 and PAX8}

The expression of TTF-1 was significantly lower in oncocytic tumours $(P=0.018)$, and significantly higher in papillary carcinomas $(P<0.001)$, compared with normal tissues (Fig. 3). PAX8 expression was significantly lower in papillary tumours $(P=0.03)$ and oncocytic tumours $(P=0.002)$ than in matched controls (Fig. 3). There was no difference in PAX8 mRNA levels in both oncocytic and papillary tumours $(P=0.26)$.

TTF-1 and PAX8 were underexpressed in 11 of the 29 oncocytomas. One of the two transcription factors, either PAX8 $(n=5)$ or TTF- $1(n=6)$, was underexpressed in 11 tumours. TTF-1 and PAX8 were normally expressed in seven tumours. When both transcription factors were underexpressed, TSHR, TG and NIS were also underexpressed in all cases. When one of the transcription factors was underexpressed, the tumours also underexpressed TG and NIS and, in some cases, TSHR as well. In one case (Fig. 2: OTA 13), both transcription factors were normally 


\begin{tabular}{|c|c|c|c|c|c|c|c|c|c|c|c|}
\hline No. & Age & $\operatorname{Sex}$ & TSнк & TG: & NIS & PAX8 & TTF-1 & TRß1 & PPARY1 & Classifieation & \\
\hline Ora 1 & 39 & $\mathrm{~F}$ & 0.11 & 0.03 & -0.01 & 0.09 & 0.7 & 0.55 & 0.42 & \multirow{17}{*}{ 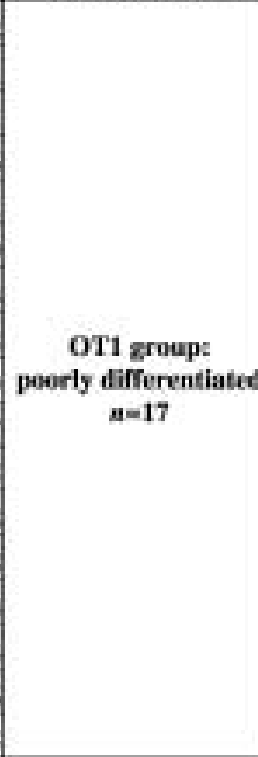 } & \\
\hline Ora 2 & 58 & M & 0.15 & 0.02 & $<0.01$ & 0.25 & 0.55 & 0.32 & 0.61 & & \\
\hline OTA 3 & 34 & $\mathrm{~F}$ & 0.09 & 0.08 & $<0,01$ & 0.55 & 0.57 & 0.5 & 0.41 & & \\
\hline ora 4 & 62 & $\mathbf{F}$ & 0.08 & 0.1 .3 & <0,01 & 0.63 & 0.3 & 0.13 & 0.16 & & \\
\hline ore 1 & 40 & $\mathbf{F}$ & 0.08 & 0.14 & c0.01 & 0.45 & 0.26 & 0.33 & 0.1 & & \\
\hline OTA 5 & 56 & $\mathrm{~F}$ & 0.26 & 0.28 & 0.01 & 0.44. & 0.61 & 0.18 & 0.39 & & \\
\hline orre 2 & 52 & $\mathrm{~F}$ & 0.33 & 0.2 & 0.03 & 1.16 & 0.47 & 0.02 & 0.53 & & \\
\hline OTA 6 & 69 & $\mathrm{~F}$ & 0.16 & 0.43 & $<0,01$ & 0.29 & 0.47 & 0.42 & 0.34 & & \\
\hline ore 3 & 44 & $\mathrm{~F}$ & 0.1 & 0.5 & <0,01 & 0.74 & 0.32 & 0.15 & 1.19 & & \\
\hline or: 7 & 45 & $\mathrm{~F}$ & 0.27 & 0.41 & el, 01 & 0.81 & 0.49 & 0.56 & 0.17 & & \\
\hline orre 4 & 38 & F & 0.55 & 0.1 .3 & 0.02 & 0.51 & 1.35 & 1.22 & 0.65 & & \\
\hline OTA 8 & 71 & F & 0.5 & 0.23 & 0.05 & 0.35 & 2.88 & 1.66 & 0.48 & & \\
\hline OTA 9 & 47 & $\mathbf{F}$ & 0.51 & 0.3 & $<0.01$ & 0.08 & 0.18 & 0.12 & 0.28 & & \\
\hline OTA 10 & 69 & $\mathrm{~F}$ & 0.26 & 0.57 & $<0,01$ & 0.47 & 0.15 & 0.18 & 0.4 & & \\
\hline OrA 11 & 69 & $\mathrm{~F}$ & 0.52 & 0.38 & 0.01 & 0.61 & 0.44 & 0.08 & 0.44 & & \\
\hline OrA 12 & 71 & $\mathrm{~F}$ & 0.49 & 0.7 & 0.02 & 0.51 & 1.15 & 0.9 & 0.36 & & \\
\hline ora 13 & 58 & $\mathrm{~F}$ & 0.53 & 0.63 & 0.36 & 1.00 & 1.28 & 1.01 & 0.95 & & \\
\hline OrTA 14 & 57 & $\mathrm{~F}$ & 1.08 & 0.52 & 0.07 & 0.5 & 0.82 & 1.06 & 1.11 & \multirow{5}{*}{$\begin{array}{c}\text { OT2 group: } \\
\text { moderately } \\
\text { differentiated } \\
n=5\end{array}$} & \\
\hline OTA 15 & 40 & $\mathrm{~F}$ & 1.06 & 0.4 & 0.37 & 0.88 & 0.07 & 0.01 & 0.78 & & \\
\hline ors if: & 43 & $\mathrm{~F}$ & 0,79 & 0.41 & 0.74 & 1.62 & 0.45 & 0.22 & 0.59 & & \\
\hline orres & 63 & $\mathrm{M}$ & 1.00 & 0.29 & 0.66 & 0.65 & 0.76 & 0.77 & 0.94 & & \\
\hline ora 17 & 56 & $\mathbf{F}$ & 1.2 .3 & 0.23 & 0.61 & 0.76 & 0.42 & 0.34 & 1.26 & & \\
\hline Ora is & 48 & $F$ & 0.76 & 1.25 & 0.0 .3 & 0.75 & 0.8 & 0.45 & 0.49 & \multirow{5}{*}{$\begin{array}{c}\text { OT3 group: } \\
\text { well differentiated } \\
n=5\end{array}$} & \\
\hline OTA 19 & 55. & $\mathrm{M}$ & 0.84 & 1.36 & 0.09 & 0.96 & 1.06 & 1.89 & 1.19 & & \\
\hline OrA 20 & 40 & $\mathrm{~F}$ & 0.84 & 1.81 & $<0.01$ & 1.17 & 1.2 & 1.36 & 2.12 & & \\
\hline OTA 21 & 44 & $\mathrm{~F}$ & $2.7 \mathrm{~K}$ & 0.78 & 0.28 & 2.27 & 1.24 & 1.28 & 3.35 & & \\
\hline OrA 22 & 4,3 & $\mathrm{~F}$ & 8.51 & 6.14 & 0.57 & 3,1 & 2.76 & 1.1 .4 & 3.81 & & \\
\hline Ora 23 & 63 & $\mathrm{~F}$ & 1.55 & 0.79 & 0.93 & 0.85 & 1.21 & 0.93 & 1.02 & \multirow{2}{*}{$\begin{array}{c}\text { Unclassiflable } \\
n=2\end{array}$} & \\
\hline Ora 24 & 58 & F & 0.59. & 3.5 & 45.79 & 1.03 & 0.69 & 0.45 & 0.78 & & \\
\hline PrC I & 51 & $\mathrm{~F}$ & 0.22 & 0.17 & 0.02. & 0.24 & 0.66 & 0.35 & 0.16 & \multirow{5}{*}{$\begin{array}{l}\text { PCI group: } \\
\text { poorty differentiated } \\
n=3 \pm 2\end{array}$} & \multirow{12}{*}{ 吾 } \\
\hline PTC 2 & 53 & M & 0.32 & 0.16 & 0,01 & 0.32 & 0.84 & 0.75 & 0.17 & & \\
\hline PTC 3 & 41 & $\mathbf{F}$ & 0,71 & 0.6 .3 & 0.0.13. & 1.4 & 2.31 & 1.22 & 0.5? & & \\
\hline PTC \& & $2 I$ & $F$ & 0.67 & 0.12 & $<0.0 I$ & 0.17 & 18.75 & 1.42 & 0.23 & & \\
\hline PTC 5 & 68 & $F$ & a.74 & a.4I & 0.02 & 0.5 & 0.74 & 0.3 & 0.24 & & \\
\hline PTC 6 & 35 & $F$ & 0.84 & 0.64 & Cod $0 I$ & $0.4 I$ & 1.14 & $1.3 \mathrm{~s}$ & 0.23 & \multirow{3}{*}{$\begin{array}{l}\mathrm{PC} 2 \text { group: } \\
\text { moderately } \\
\text { differentiated } \\
n= \pm 3\end{array}$} & \\
\hline PTC 7 & 70 & $F$ & 1.29 & 0.36 & cel.0I & 2.58 & 8.14 & 6.01 & 0.14 & & \\
\hline PTC 8 & 18 & $F$ & 1.01 & 0.69 & 0.05 & 0.57 & 3.48 & 1.1 & 0.29 & & \\
\hline PTC 9 & 31 & $\mathrm{~F}$ & 1.12 & 1.19 & 0.01 & 0.65 & 0.19 & 0.01 & 0.15 & \multirow{4}{*}{$\begin{array}{c}\text { PC3 groups } \\
\text { well differentiated } \\
N=4\end{array}$} & \\
\hline PTC 10 & 31 & $\mathrm{~F}$ & 1.23 & 1.26 & 0.01 & 0.81 & 1.77 & 1.1 & 0.38 & & \\
\hline PTC 11 & 46 & $\mathrm{~F}$ & 1.01 & 1.61 & 0,07 & 0.56 & 1.6 & 3.11 & 0.27 & & \\
\hline PTC 12 & 31 & $\mathrm{~F}$ & 1.41 & 1.98 & 0.02 & 1.16 & 1.27 & 0.76 & 0.36 & & \\
\hline
\end{tabular}

Figure 2 Expression of TSHR, NIS, TG, PAX8, TTF-1, PPAR 1 and TR $\beta 1$ in oncocytic tumours (OTA, oncocytic thyroid adenoma, white boxes; OTC, oncocytic thyroid carcinoma, grey boxes) and papillary carcinomas (PTC, papillary thyroid carcinoma). Quantification of each messenger was normalised to $\beta$-ACTIN copy number for tumour thyroid $\left(R_{t}\right)$ and normal thyroid $\left(R_{n}\right)$. The gene is

underexpressed if $R_{\mathrm{t}} / R_{\mathrm{n}}$ is lower than 0.75 (light-grey boxes), normally expressed (white boxes) if the ratio is between 0.75 and 1.25 and overexpressed (dark-grey boxes) if it is higher than 1.25. Papillary carcinomas, indicated by italics, represent the tumours without normal paired tissue. 

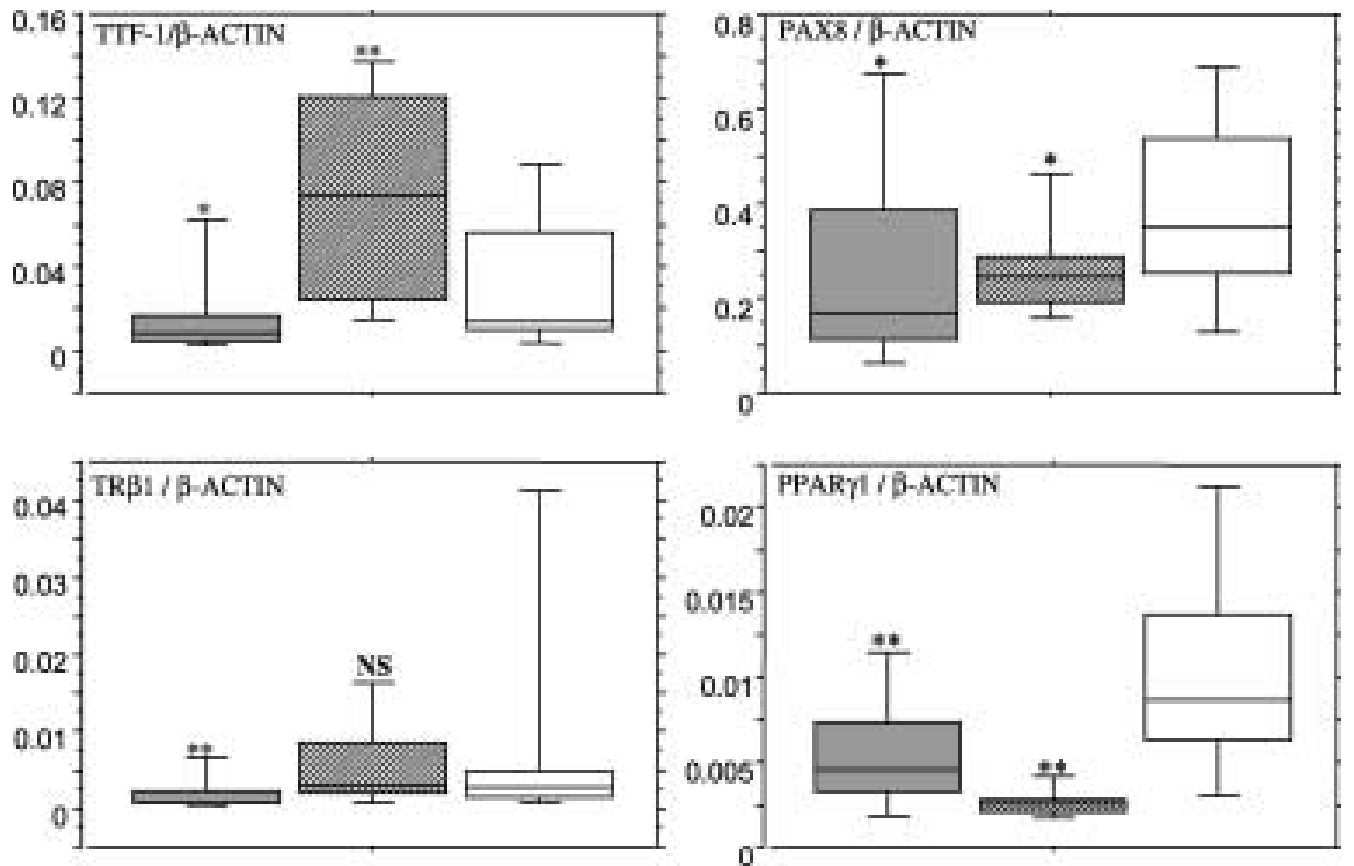

$\square$ Oncocytic tumours

Papillary carcinomas

$\square$ Normal tissues

Figure 3 Box plots for TTF1, PAX8, TR $\beta 1$ and PPAR $\gamma 1$ expression levels in 29 oncocytic tumours, 12 papillary carcinomas and 36 normal tissues by real-time quantitative PCR after $\beta$-ACTIN normalisation. Boxes enclose interquartiles, error bars indicate 10 th and 90th percentiles and centrelines indicate medians. ${ }^{\star} P \leq 0.001$; ${ }^{\star} P \leq 0.05$; NS, $P>0.05$.

expressed, even though TSHR, TG and NIS were underexpressed. In 28 of the 29 oncocytic tumours, there was a significant relationship between the level of thyroid-specific gene expression and the level of specific transcription factor expression $(P<0.0001)$.

In 3 of the 12 papillary carcinomas, TTF-1 and PAX8 were underexpressed. Two of the tumours underexpressed the three thyroid-specific genes, while the other underexpressed only NIS. None of the 12 papillary carcinomas had lost TTF-1 expression alone, whereas PAX8 expression was individually lost in five of the oncocytic tumours.

\section{Expression of other nuclear transcription factors}

The expression of the TR $\beta 1$ gene was significantly lower in follicular oncocytic tumours compared with normal paired thyroid samples $(P<0.001$, Fig. 3), but not in papillary carcinomas $(P=0.69)$. The expression profile of TR $\beta 1$ was correlated to that of TTF-1 for oncocytic tumours $\left(r^{2}=0.71, P<0.001\right)$, but not for papillary carcinomas $\left(r^{2}=0.36, P=0.17\right)$.

The expression of the PPAR $\gamma 1$ gene was significantly reduced in both follicular oncocytic tumours and papillary carcinomas compared with normal paired thyroid samples $(P<0.001$, Fig. 3). For the 29 oncocytomas, the results obtained for PPAR $\gamma 1$ were usually correlated with thyroid tumour dedifferentiation. In the OT1 group of tumours with a low expression of the three thyroid-specific genes, PPAR $\gamma 1$ was underexpressed in 15 of the 17 tumours, and normally expressed in two. In the OT2 group, the expression of PPAR $\gamma 1$ was normal in three of the five tumours. In the OT3 group, PPAR $\gamma 1$ was overexpressed in three of the five tumours (Fig. 2).

\section{Sequencing}

We sequenced exons 8 and 9 of GNAS, all coding portions of the TSHR, all coding portions of the TTF-1 and exons 7 to 10 of TR $\beta 1$ in 24 oncocytic tumours and 14 normal samples. No mutations were found on the hot spot regions of GNAS or the coding regions of the TTF-1 and TR $\beta 1$ genes. One oncocytoma (Fig. 2: OTA 24) displayed an activating mutation M453T in exon 10 of TSHR.

\section{Discussion}

Tissue array analysis of p53, mdm-2, p21, Bcl-2, cyclin D1 and Ki-67 expression has allowed identification of 
some markers of oncocytic tumours prognosis (21). However, no macro- or micro-arrays using thyroidspecific gene expression profile have been available for the classification of oncocytic tumours with reference to other differentiated follicular thyroid tumours. Our study of the expression of 7 thyroid genes and regulatory factors in 29 oncocytic tumours has enabled us to draw up a specific profile for oncocytic tumours.

The analysis of the gene expression profile allowed a subclassification of oncocytic tumours and papillary carcinomas into distinctly poorly differentiated groups, i.e. the OT1 and PC1 groups, and the well-differentiated groups, i.e. the OT3 and PC3 groups. Obviously, the subgroups defined represent various stages of a continuous dedifferentiation process. However, the subclassification has led us to determine a subgroup of oncocytic adenomas that may be associated with the worst prognosis, as suspected in oncocytic carcinomas. It has been shown that the loss of NIS expression occurs before that of TSHR and TG in the multistep process of thyroid carcinogenesis (10). The underexpression of NIS in 27 of the 29 oncoctyic tumours in our study confirms that iodide trapping is an early event in the thyroid tumourigenesis process. Two tumours with a normal or higher than normal expression of NIS escaped from our defined categories. One was an oncocytic adenoma (Fig. 2: OTA 23) that had developed in the context of Grave's disease; the other was an adenoma (Fig. 2: OTA 24) with an activating M453T mutation in the TSHR gene. The increased NIS expression in these two tumours is in accordance with a stimulation of the TSH pathway $(22,23)$.

TSH is the main regulator of the differentiation and proliferation processes of thyroid cells $(24,25)$. The discovery of somatic and germline-activating mutations in the TSHR gene and in GNAS in some follicular tumours has established the role of the cAMP cascade in both processes $(8,26)$. However, such a mechanism appears marginal in the case of oncocytomas. In our study, the expression of TSHR was significantly lower in oncocytic tumours than in papillary carcinomas $(P=0.008)$, suggesting a lower level of differentiation in oncocytomas than in papillary carcinomas. Interestingly, the low TSHR expression we observed in some oncocytic adenomas is similar to that described in poorly differentiated carcinomas (27). However, one atypical oncocytic adenoma (OTA 22) presented a highly differentiated profile with overexpression of TSHR and mild expression of NIS. We believe that TSHR as a malignant marker may select some patients who might show good responses to iodine treatment. Considering the usual difficulties for oncocytic tumour treatment, selection of the adaptive treatment on molecular marker may be interesting. As TSHR expression is regulated by TTF-1, this transcription factor may also play a role in oncocytic tumours.

The determination and the maintenance of a differentiated phenotype are controlled by transcription factors (TTF-1 and PAX8). In 28 of the 29 oncocytic tumours studied, we found a significant correlation between the loss of thyroid genes and the loss of expression of specific transcription factors. However, one oncocytoma (Fig. 2: OTA 13) expressed TTF-1 and PAX8 normally, while underexpressing the three thyroid-specific genes, suggesting that other DNA-binding proteins were involved in the decreased specific thyroid gene expression. In contrast to oncocytic tumours, the expression of TTF-1 and PAX8 was different in papillary carcinomas. These tumours underexpressed PAX8 alone more often than oncocytomas and never underexpressed TTF-1 alone. Incidentally, we found similar results in two human thyroid-cancer cell lines: BCPAP, which is a papillary carcinoma cell line, and XTC.UC1, which derives from an oncocytic thyroid carcinoma. The copy number of TTF-1 mRNA normalised to $\beta$-ACTIN, was five times greater for BCPAP than for XTC.UC1 whereas the copy number of PAX8 was the same (data not shown).

The study of TR $\beta 1$ and PPAR $\gamma 1$ expression levels showed that there was no correlation between the expression of PPAR $\gamma 1$ and that of TTF-1, whereas there was good correlation between the expression of TR $\beta 1$ and that of TTF-1, particularly in the case of oncocytic tumours. Three mechanisms may explain this observation: a protein-protein interaction, similar to that described for TTF-1 and the retinoic acid receptor (28), coordinated upstream control, or a transcriptional effect. We tested the hypothesis of a possible transcriptional effect by means of an analytical program described elsewhere (29), and discovered two putative thyroid response elements (TRE) in the promoter of TTF- 1 .

We have tried to match the differentiation profile of the tumours, based on the quantification of seven mRNAs (TSHR, TG, NIS, TTF-1, PAX8, TR $\beta 1$ and PPAR $\gamma 1$ ), to their histopathological features. The molecular expression profiles were concordant with the morphological observations in 16 of the 29 oncocytic tumours studied. However, it is interesting to note that all five oncocytic carcinomas in our study belonged to the less differentiated groups (OT1 and OT2). This is in contrast to a study reporting differentiation in similar tumours (12). Unfortunately, the number of carcinomas in both these studies is too small to allow statistical analysis. We believe that the use of the quantitative RT-PCR method and paired control tissues allows a better subclassification of oncocytomas. Using the criteria of low TSHR, TG and NIS gene expression, 13 oncocytic adenomas were classified in the poorly differentiated group (OT1). As four of the five oncocytic carcinomas were classified in this group, we suggest that these adenomas with discordant morphogenetic results may in fact be pre-invasive carcinomas. To confirm this suggestion, we should increase the follow-up of our patients diagnosed for less than 5 years.

Our study showed that the expression of TSHR, TTF-1 and TR $\beta 1$ was significantly lower in oncocytic 
tumours than in papillary carcinomas. The down-regulation of TSHR expression may be associated with the modification of the cellular location or function of TTF-1 and TR $\beta 1$. Therefore, patients with oncocytic adenomas presenting low TSHR mRNA levels could benefit from a prolonged follow-up.

\section{Acknowledgements}

We are grateful to $\mathrm{M}$ Ferre for bioscience computing analysis and to $\mathrm{K}$ Malkani for his critical reading of the manuscript. This work was supported by grants from the Regional Delegation for Clinical Research of the University Hospital of Angers (PHRC PL 01-10).

\section{References}

1 Kendall CH, McCluskey E \& Meagles JN. Oxyphil cells in thyroid disease: a uniform change? Journal of Clinical Pathology 198639 908-912.

2 Tallini G. Oncocytic tumours. Virchows Archivs 1998 433 5-12.

3 Hundahl SA, Cady B, Cunningham MP, Mazzaferri E, McKee RF, Rosai J et al. Initial results from a prospective cohort study of 5583 cases of thyroid carcinoma treated in the United States during 1996. U.S. and German Thyroid Cancer Study Group. An American College of Surgeons Commission on Cancer Patient Care Evaluation study. Cancer $200089202-217$.

4 Dechet CB, Sebo T, Farrow G, Blute ML, Engen DE \& Zincke H. Prospective analysis of intraoperative frozen needle biopsy of solid renal masses in adults. Journal of Urology $1999 \mathbf{1 6 2}$ $1282-1285$.

5 Perez-Ordonez B, Hamed G, Campbell S, Erlandson RA, Russo P, Gaudin PB et al. Renal oncocytoma: a clinicopathologic study of 70 cases. American Journal of Surgical Pathology $1997 \mathbf{2 1}$ $871-883$.

6 Laurent E, Mockel J, Van Sande J, Graff I \& Dumont JE. Dual activation by thyrotropin of the phospholipase $C$ and cyclic AMP cascades in human thyroid. Molecular and Cellular Endocrinology 198752 273-278.

7 Esapa C, Foster S, Johnson S, Jameson JL, Kendall-Taylor P \& Harris PE. G protein and thyrotropin receptor mutations in thyroid neoplasia. Journal of Clinical Endocrinology and Metabolism $199782493-496$.

8 Parma J, Duprez L, Van Sande J, Cochaux P, Gervy C, Mockel J et al. Somatic mutations in the thyrotropin receptor gene cause hyperfunctioning thyroid adenomas. Nature $1993 \quad \mathbf{3 6 5}$ 649-651.

9 Suarez HG. Genetic alterations in human epithelial thyroid tumours. Clinical Endocrinology $1998 \mathbf{4 8} 531-546$.

10 Filetti S, Bidart JM, Arturi F, Caillou B, Russo D \& Schlumberger M. Sodium/iodide symporter: a key transport system in thyroid cancer cell metabolism. European Journal of Endocrinology 1999 $141443-457$.

11 Fabbro D, Di Loreto C, Beltrami CA, Belfiore A, Di Lauro R \& Damante G. Expression of thyroid-specific transcription factors TTF-1 and PAX-8 in human thyroid neoplasms. Cancer Research $1994 \mathbf{5 4} 4744-4749$.

12 Ros P, Rossi DL, Acebron A \& Santisteban P. Thyroid-specific gene expression in the multi-step process of thyroid carcinogenesis. Biochimie 199981 389-396.

13 Chen ST, Lin JD \& Lin KH. Characterisation of a thyroid hormonemediated short-loop feedback control of TSH receptor gene in an anaplastic human thyroid cancer cell line. Journal of Endocrinology $2002175459-465$.
14 Bronnegard M, Torring O, Boos J, Sylven C, Marcus C \& Wallin G. Expression of thyrotropin receptor and thyroid hormone receptor messenger ribonucleic acid in normal, hyperplastic, and neoplastic human thyroid tissue. Journal of Clinical Endocrinology and Metabolism $199479384-389$.

15 Puzianowska-Kuznicka M, Krystyniak A, Madej A, Cheng SY \& Nauman J. Functionally impaired TR mutants are present in thyroid papillary cancer. Journal of Clinical Endocrinology and Metabolism 200287 1120-1128.

16 Kroll TG, Sarraf P, Pecciarini L, Chen CJ, Mueller E, Spiegelman $\mathrm{BM}$ et al. PAX8-PPARgamma1 fusion oncogene in human thyroid carcinoma. Science $2000 \mathbf{2 8 9} 1357-1360$.

17 Sarraf P, Mueller E, Smith WM, Wright HM, Kum JB, Aaltonen LA et al. Loss-of-function mutations in PPAR gamma associated with human colon cancer. Molecular Cell 19993 799-804.

18 Marques AR, Espadinha C, Catarino AL, Moniz S, Pereira T, Sobrinho LG et al. Expression of PAX8-PPAR gamma 1 rearrangements in both follicular thyroid carcinomas and adenomas. Journal of Clinical Endocrinology and Metabolism 200287 3947-3952.

19 Hedinger C, Williams ED \& Sobin LH. The WHO histological classification of thyroid tumors: a commentary on the second edition. Cancer $198963908-911$.

20 Savagner F, Franc B, Guyetant S, Rodien P, Reynier P \& Malthiery Y. Defective mitochondrial ATP synthesis in oxyphilic thyroid tumors. Journal of Clinical Endocrinology and Metabolism $2001864920-4925$.

21 Hoos A, Stojadinovic A, Singh B, Dudas ME, Leung DH, Shaha AR et al. Clinical significance of molecular expression profiles of Hürthle cell tumors of the thyroid gland analyzed via tissue microarrays. American Journal of Pathology $2002160175-183$.

22 Lazar V, Bidart JM, Caillou B, Mahe C, Lacroix L, Filetti S et al. Expression of the $\mathrm{Na}^{+} / \mathrm{I}^{-}$symporter gene in human thyroid tumors: a comparison study with other thyroid-specific genes. Journal of Clinical Endocrinology and Metabolism $1999 \mathbf{8 4}$ 3228-3234.

23 Saito T, Endo T, Kawaguchi A, Ikeda M, Nakazato M, Kogai T et al. Increased expression of the $\mathrm{Na}^{+} / \mathrm{I}^{-}$symporter in cultured human thyroid cells exposed to thyrotropin and in Graves' thyroid tissue. Journal of Clinical Endocrinology and Metabolism $1997 \mathbf{8 2}$ 3331-3336.

24 Marians RC, Ng L, Blair HC, Unger P, Graves PN \& Davies TF. Defining thyrotropin-dependent and -independent steps of thyroid hormone synthesis by using thyrotropin receptor-null mice. PNAS $20029915776-15781$.

25 Postiglione MP, Parlato R, Rodriguez-Mallon A, Rosica A, Mithbaokar P, Maresca M et al. Role of the thyroid-stimulating hormone receptor signaling in development and differentiation of the thyroid gland. PNAS 200299 15462-15467.

26 Derwahl M. TSH receptor and Gs-alpha gene mutations in the pathogenesis of toxic thyroid adenomas-a note of caution. Journal of Clinical Endocrinology and Metabolism $1996812783-2785$.

27 Sheils OM \& Sweeney EC. TSH receptor status of thyroid neoplasms - TaqMan RT-PCR analysis of archival material. Journal of Pathology $1999 \mathbf{1 8 8} 87-92$.

28 Yan C, Naltner A, Conkright J \& Ghaffari M. Protein-protein interaction of retinoic acid receptor alpha and thyroid transcription factor-1 in respiratory epithelial cells. Journal of Biological Chemistry 2001276 21686-21691.

29 Hertz GZ, Hartzell GW \& Stormo GD. Identification of consensus patterns in unaligned DNA sequences known to be functionally related. Computer Applications in the Biosciences 19906 81-92.

Received 25 August 2003

Accepted 21 November 2003 